\title{
What Is pH and Why Do We Care?
}

M. J. SINGER, Professor of Soil Science and UC Cooperative Extension Soil Resource Specialist, Department of Land, Air, and Water Resources, UC Davis; $\mathbf{H}$.

A. GEORGE, UC Cooperative Extension Livestock and Natural Resources Advisor, Plumas County; C. D. CHILDERS, UC Cooperative Extension Administrative Assistant for Plumas-Sierra Counties; and M. L. MERRILL-DAVIES, UC Cooperative Extension Livestock and Natural Resources Farm Advisor, Modoc County

\section{WHAT IS PH?}

In chemistry, $\mathrm{pH}$ is defined as the negative logarithm of the hydrogen-ion activity. More simply, it is a measure of the relative amount of free hydrogen $(\mathrm{H}+)$ and hydroxyl ions $(\mathrm{OH}-)$. That is, it tells the degree to which something-such as soil, water, or any solution-is basic or acidic. $\mathrm{pH}$ is reported in logarithmic units, like the Richter scale, which represents strength of earthquakes. Each number represents a tenfold change in the acidity or alkalinity of a substance. The range goes from 0 to 14 , and around 7 is considered neutral. For example, water with a $\mathrm{pH}$ of 5 is ten times more acidic than water with a $\mathrm{pH}$ of 6 . Additionally, $\mathrm{pH}$ of less than 7 indicates acidity, whereas a $\mathrm{pH}$ of greater than 7 indicates alkalinity or a base.

This figure shows the $\mathrm{pH}$ range of several familiar materials.

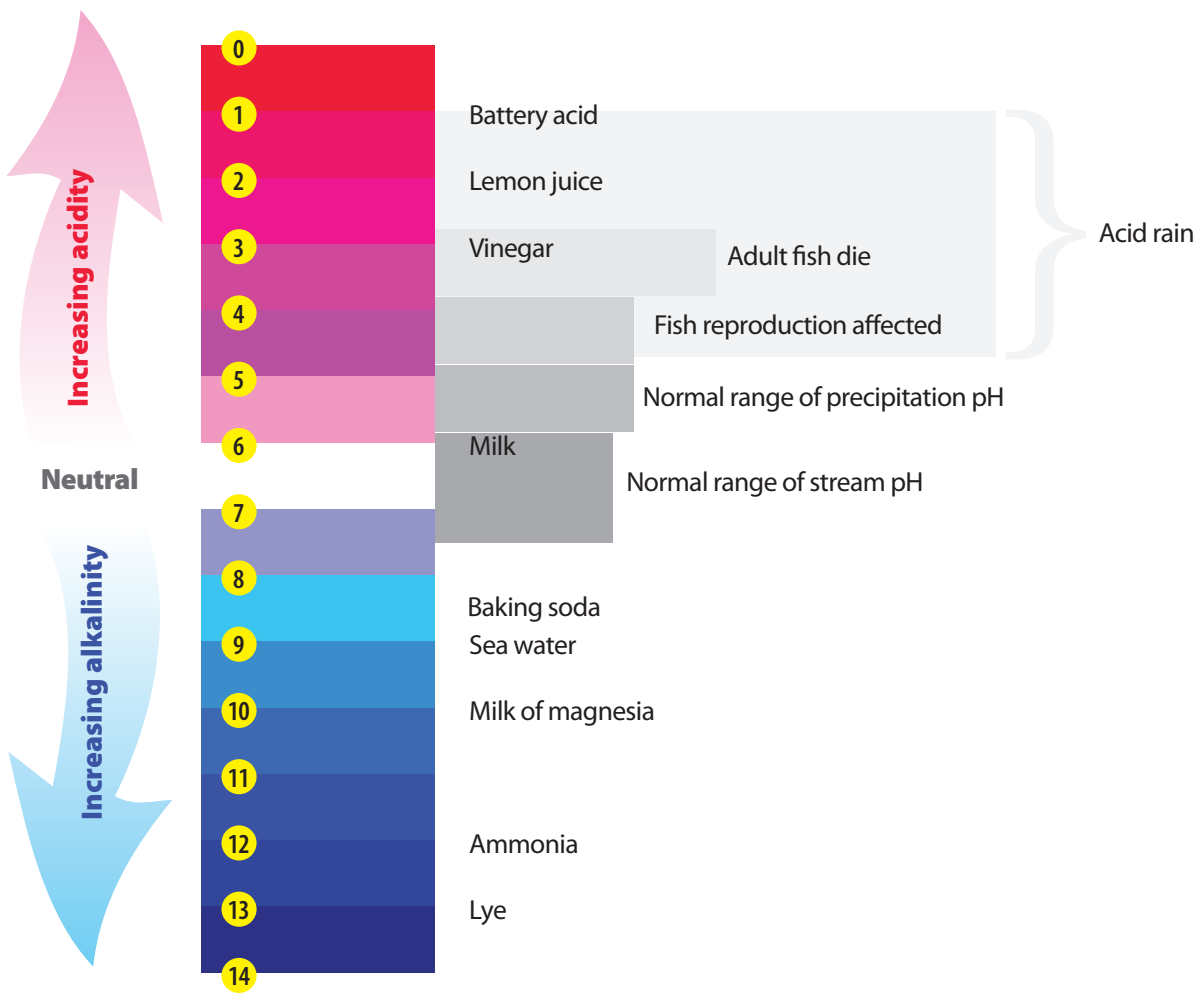

Source: Modified from "Acid Rain," Environment Canada, 2012

(http://www.ec.gc.ca/eau-water/default.asp?lang=En\&n=FDF30C16-1). 


\section{Why Do We Care?}

Soil $\mathbf{p H}$. The $\mathrm{pH}$ value of a soil is influenced by many factors, including vegetation, topography, mineralogy, texture, and the kinds of parent materials from which the soil was formed. Soils that are developed from basic rocks, such as basalt rocks found in the Warner Mountains in California, generally have higher $\mathrm{pH}$ values than those formed from acidic rocks, such as the granite rocks found in the Sierra Nevada Mountains of California. Rainfall also affects soil $\mathrm{pH}$. Water passing through the soil leaches basic nutrients, such as calcium, sodium, potassium, and magnesium, from the soil. They are replaced by acidic elements, such as aluminum and hydrogen. For this reason, soils formed under high rainfall conditions are more acidic than those formed under arid conditions. Application of fertilizers containing ammonium or urea adds to soil acidity. The decomposition of organic matter also adds to soil acidity.

Optimal plant growth is dependent on soil $\mathrm{pH}$ because it affects the availability of all plant nutrients. Plant production and health are impaired at either high $(>8)$ or low $(<6) \mathrm{pH}$, because of nutrient limitations and potential toxicities. A pH of 6.0 to 6.5 is in an ideal range that optimizes the availability of many micro- and macronutrients. It also minimizes the toxicity of some micronutrients, some of which can be toxic at extreme $\mathrm{pH}$. In highly acid soils, aluminum and manganese can become more available and more toxic to the plant. Another effect of low $\mathrm{pH}$ is that calcium, phosphorus, and magnesium are less available to the plant. At a pH of 6.5 and above, phosphorus and most of the micronutrients become less available. $\mathrm{pH}$ directly affects how fertilizers change into a form that plants can easily uptake. Different environments will influence the $\mathrm{pH}$ needs of an agricultural crop. However, most productive agricultural soils range from 6.0 to 7.5.

Water $\mathbf{p H}$. The $\mathrm{pH}$ of water is most affected by the soils through which the water flows before getting into the stream, ditch, or river channel. Additionally, many other factors influence the $\mathrm{pH}$ of stream water: the source of the water, precipitation, root and microbial respiration, and contaminants. The only one of these factors that can be controlled is the input of contaminants.
The main use of $\mathrm{pH}$ in a water analysis is for detecting abnormal water. The normal $\mathrm{pH}$ range for irrigation water is from 6.5 to 8.4. An abnormal value is a warning that the water needs further evaluation. Irrigation water with a $\mathrm{pH}$ outside the normal range may cause a nutritional imbalance or may contain a toxic ion.

Low-salinity water sometimes has a $\mathrm{pH}$ outside the normal range since it has a very low buffering capacity. This should not cause undue alarm but should alert the user to a possible imbalance of ions and the need to establish the reason for the adverse $\mathrm{pH}$ through a full laboratory analysis. Such water normally causes few problems for soils or crops but is very corrosive and may rapidly corrode pipelines, sprinklers, and control equipment, especially when associated with a low $\mathrm{pH}$.

Pollution can change water's $\mathrm{pH}$, which in turn can harm plants and animals living in the water. Pollution is categorized by its source point or nonpoint. Point source pollution is an observable, specific, discharge of pollutants into a water body, for example, from feedlots. Nonpoint source pollution consists of diffuse discharges of pollutants through the natural environment, and it is usually associated with agriculture and forestry. One of the main nonpoint source contaminants of concern is phosphorus. Phosphorus contamination leads to blooms in microbial population, which increase the amount of carbon dioxide in the water source. Increasing carbon dioxide leads to a decrease in $\mathrm{pH}$, thus making the water more acidic.

Water $\mathrm{pH}$ can vary with seasonal temperature changes. One of the causes for this is microbial respiration and the resulting carbon dioxide. Carbon dioxide is more soluble at cooler temperatures, thus decreasing the $\mathrm{pH}$ and making the water more acidic. Conversely, carbon dioxide is less soluble in warmer temperatures but there is more respiration taking place, so the actual change in $\mathrm{pH}$ is variable.

\section{HOW do WE MEASURE PH?}

Soil $\mathbf{p H}$. It is important to know the $\mathrm{pH}$ of soil before seeding any plant. By knowing the $\mathrm{pH}$ of the soil, a person can choose plants that are adapted to that condition or amend the soil to fit the chosen crop's needs. A soil test performed by a trustworthy lab is relatively inexpensive and will also have other 
information incorporated in it. Soil $\mathrm{pH}$ can also be measured using $\mathrm{pH}$ meters, standard dyes, or paper $\mathrm{pH}$ indicator strips. Each has pros and cons related to its ease of use, capability, hardiness, and expense.

Water $\mathrm{pH}$. The same three methods for measuring $\mathrm{pH}$ in soil can be used in measuring $\mathrm{pH}$ in water. The main difference is that water should be measured as soon as possible after taking the sample.
This will decrease changes due to temperature variations, microbial respiration, and so on.

As discussed previously, the level of $\mathrm{pH}$ in soils and water has a significant impact on the productivity, sustainability, and relative health of an area. Measuring $\mathrm{pH}$ is a fairly simple, cost-effective process. Plans for monitoring $\mathrm{pH}$ can be developed with the local farm advisor.

\section{FOR FURTHER INFORMATION}

To order or obtain ANR publications and other products, visit the ANR Communication Services online catalog at http://anrcatalog.ucanr.edu or phone 1-800-994-8849. You can also place orders by mail or FAX, or request a printed catalog of our products from

\author{
University of California \\ Agriculture and Natural Resources \\ Communication Services \\ 1301 S. 46th Street \\ Building 478 - MC 3580 \\ Richmond, CA 94804-4600 \\ Telephone 1-800-994-8849 \\ 510-665-2195 \\ FAX 510-665-3427 \\ E-mail: anrcatalog@ucanr.edu \\ (C)2012 The Regents of the University of California \\ Agriculture and Natural Resources \\ All rights reserved.
}

\section{Publication 8488}

\section{ISBN-13: 978-1-60107-827-8}

The University of California Division of Agriculture \& Natural Resources (ANR) prohibits discrimination against or harassment of any person participating in any of ANR's programs or activities on the basis of race, color, national origin, religion, sex, gender identity, pregnancy (which includes pregnancy, childbirth, and medical conditions related to pregnancy or childbirth), physical or mental disability, medical condition (cancer-related or genetic characteristics), genetic information (including family medical history), ancestry, marital status, age, sexual orientation, citizenship, or service in the uniformed services (as defined by the Uniformed
Services Employment and Reemployment Rights Act of 1994: service in the uniformed services includes membership, application for membership, performance of service, application for service, or obligation for service in the uniformed services) or any person in any of its programs or activities.

University policy also prohibits retaliation against any employee or person participating in any of ANR's programs or activities for bringing a complaint of discrimination or harassment pursuant to this policy. This policy is intended to be consistent with the provisions of applicable State and Federal laws.

Inquiries regarding the University's equal employment opportunity policies may be directed to Linda Marie Manton, Affirmative Action Contact, University of California, Davis, Agriculture and Natural Resources, One Shields Avenue, Davis, CA 95616, 530752-0495. For assistance in downloading this publication, telephone 530-754-3927.

An electronic copy of this publication can be found at the ANR Communication Services catalog website, http://anrcatalog. ucanr.edu.

UEER

This publication has been anonymously peer reviewed for technical accuracy by University of California scientists and other qualified professionals. This review process was managed by the ANR Associate Editor for Land, Air, and Water Sciences, Toby O'Geen.

web-10/12-LR/CR 